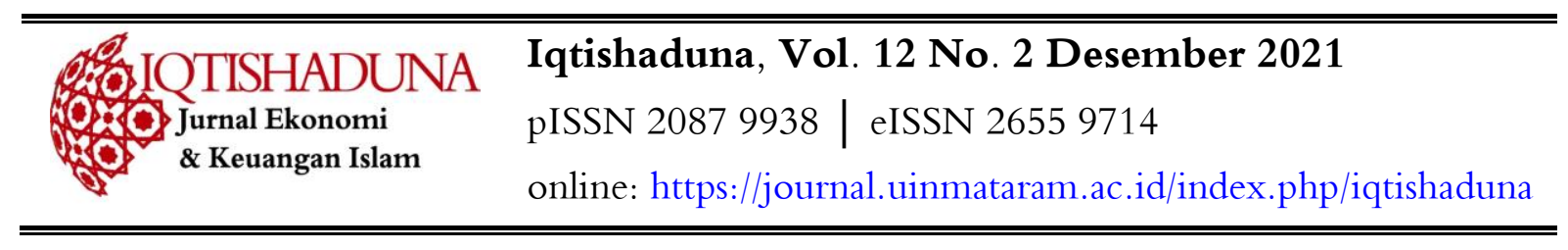

\title{
ANALISIS PENGARUH PELATIHAN DAN JAM KERJA TERHADAP KINERJA KARYAWAN PNM MEKAAR SYARIAH DI KOTA DEPOK
}

\author{
Rizky Fadhila ${ }^{1}$, Izzani Ulfi ${ }^{2}$ \\ Program Studi Ekonomi Syariah Universitas Gunadarma \\ rifadhila27@gmail.com¹ ${ }^{1}$, izzani@,staff.gunadarma.ac.id ${ }^{2}$
}

\begin{abstract}
Human resource is an asset for any institution including Islamic financial institutions. Their performance would also determine the success of the institution. Therefore, this study aims to check the influence of training and working hours variables on the performance of PNM Mekaar Syariah employees Depok. Primary data has been collected through questionnaires. Purposive sampling technique has been used and 67 employees PNM Mekaar Syariah Depok have participated in the questionnaires. For data analysis, Multiple Regression Analysis is employed and processed using SPSS 25. The result shows that based on the t-test, both training and working hours variables do not affect the performance of employees. However, it is found that based on the $\mathrm{F}$ test, training variables and working hours are simultaneously affect the performance of PNM Mekaar Syariah employees in Depok City.
\end{abstract}

Keywords: Training, Working Hours, Employee Performance

\section{PENDAHULUAN}

Dewasa ini perkembangan industri perbankan syariah menunjukkan kemajuan yang cukup pesat, berdasarkan data statistik Otoritas Jasa Keuangan (OJK) pada Agustus 2020 total Bank Umum Syariah dan Unit Usaha Syariah sebanyak 40 dengan jumlah kantor sebanyak 2.327 yang tersebar di seluruh wilayah Nusantara, serta total tenaga kerja yang mencapai angka 55.062 orang.

Dalam menjalankan operasionalnya, bank syariah dan lembaga keuangan syariah tentunya membutuhkan Sumber Daya Manusia (SDM). SDM merupakan perangkat utama yang akan mendukung kelancaran aktivitas suatu perusahaan, karena manusia merupakan faktor tenaga kerja yang dapat tumbuh dan berkembang (Sukoco, 2020). Untuk mendukung perkembangan ekonomi berbasis syariah tersebut tentunya harus didukung dengan SDM yang memiliki kinerja terbaik.

Untuk mencapai kinerja yang baik, salah satu hal yang mendukung adalah pelatihan. Pelatihan menjadi sesuatu yang krusial bagi karyawan, terutama dalam lembaga keuangan syariah yang masih termasuk dalam kategori pengembangan dan pengenalan kepada masyarakat. Menurut Naim (2019) pelatihan merupakan kegiatan pengembangan sumber daya manusia untuk meningkatkan pengetahuan, kemampuan dan keterampilan, serta meningkatkan kinerja pegawai. Adapun menurut Rachmawati (dalam Sofiana, 2018) pelatihan merupakan wadah lingkungan bagi 
karyawan, dimana mereka memperoleh atau mempelajari sikap, kemampuan, keahlian, pengetahuan, dan perilaku spesifik yang berkaitan dengan pekerjaan.

Selain itu, terdapat faktor lain yang mempengaruhi kinerja karyawan yaitu jam kerja karyawan. Jam kerja merupakan hal yang perlu diperhatian bagi karyawan maupun perusahaan. Karena hal ini bisa mempengaruhi produktivitas karyawan yang tentunya juga akan berdampak kepada target yang ingin dicapai oleh perusahaan itu sendiri. Menurut Kosasih (2009) menyatakan bahwa pengaturan waktu termasuk dalam perencanaan tenaga kerja yang berkenaan dengan jadwal kerja dan jumlah tenaga kerja yang akan dipertahankan. Hal ini dipertegas oleh UU No. 13 tahun 2003 yang mewajibkan setiap pengusaha untuk melaksanakan ketentuan jam kerja. Dengan adanya ketentuan jam kerja tersebut, seharusnya perusahaan dapat mematuhi dan menerapkan peraturan yang berlaku. Namun dengan banyaknya beban kerja karyawan PNM Mekaar Syariah seperti memenuhi target jumlah nasabah, penarikan angsuran, dan memimpin perkumpulan kelompok tanggung renteng nasabah membuat karyawan harus bekerja diluar jam kerja.

Bagi sebuah lembaga yang bertugas memberikan pelayanan kepada masyarakat, tentu saja kinerja pegawai dapat dilihat dari bagaimana lembaga tersebut dalam memberikan pelayanan kepada masyarakat. Pelayanan yang baik akan meningkatkan kepuasan untuk dapat memenangkan persaingan. Kinerja karyawan merupakan hal yang sangat penting untuk diperhatikan, karena akan mempengaruhi kualitas dari sebuah perusahaan. Oleh sebab itu, memiliki karyawan yang berkualitas sangat dibutuhkan agar tujuan dari perusahaan dapat tercapai dengan meningkatkan kinerja dari karyawan perusahaan itu sendiri.

Dengan menggunakan regresi linier berganda, penelitian ini bertujuan untuk menguji bagaimana pengaruh pelatihan dan jam kerja terhadap kinerja pada PNM Mekaar Syariah di Depok. Studi ini diharapkan dapat memberikan manfaat pada PNM Mekaar Syariah terkait dengan kebijakan pelatihan yang diberikan dan jam kerja yang ditentukan terhadap peningkatan performa kerja para pegawainya di masa yang akan datang.

\section{STUDI LITERATUR}

A. Kinerja

Kinerja adalah hasil kerja yang mampu dicapai oleh seseorang atau sekelompok orang dalam suatu organisasi baik secara kualitatif dan kuantitatif, sesuai dengan kewenangan dan tugas tanggung jawabnya, dalam upaya mencapai tujuan organisasi serta tidak melanggar hukum dan sesuai dengan moral atau etika (Mangkunegara, 2015).

Menurut Wirawan (2009), ada beberapa faktor yang dapat mempengaruhi kinerja karyawan dalam sebuah organisasi atau perusahaan yang terbagi menjadi tiga kelompok, yaitu: 
Fadhila \& Ulfi.

a. Faktor lingkungan internal organisasi

Merupakan dukungan dari perusahaan tempat karyawan bekerja, dukungan tersebut akan sangat mempengaruhi tingkat kinerja karyawan.

b. Faktor lingkungan eksternal organisasi

Merupakan keadaan, kejadian, atau pun situasi yang terjadi di lingkungan eksternal organisasi yang bisa mempengaruhi kinerja karyawan.

c. Faktor internal karyawan

Merupakan faktor yang bersumber dari dalam diri karyawan itu sendiri yang merupakan faktor bawaan dari lahir dan faktor yang diperoleh ketika ia berkembang.

Menurut Wibowo (2007), pengukuran kinerja yang tepat dapat dilakukan dengan cara:

a. Memastikan bahwa keinginan pelanggan telah terpenuhi

b. Mengusahakan standar kinerja yang baik untuk membuat perbandingan

c. Mengusahakan jarak bagi orang lain untuk memonitor tingkat kinerja karyawan

d. Menetapkan arti penting masalah kualitas dan menetukan apa yang perlu menjadi prioritas perhatian karyawan

e. Menghindari konsekuensi dari rendahnya kualitas

f. Mempertimbangkan penggunaan sumber daya

g. Mengusahakan umpan balik untuk mendorong usaha yang lebih baik.

B. Pelatihan

Pada dasarnya pelatihan berarti proses memberi bantuan kepada para karyawan untuk menguasai suatu keterampilan khusus atau membantu memperbaiki kekurangannya dalam melakukan pekerjaan. Pelatihan diadakan dengan berbagai maksud dan tujuan yang ingin dicapai oleh suatu organisasi atau instansi. Menurut Mangkunegara (2015) tujuan dari pelatihan adalah:

a. Meningkatkan penghayatan jiwa dan ideologi.

b. Meningkatkan produktivitas kerja.

c. Meningkatkan kualitas kerja.

d. Meningkatkan ketetapan perencanaan sumber daya manusia.

e. Meningkatkan moral semangat kerja.

f. Meningkatkan rangsangan agar karyawan mampu berprestasi secara maksimal.

g. Meningkatkan kesehatan dan keselamatan kerja.

h. Menghindari keusangan.

i. Meningkatkan perkembangan pribadi karyawan.

Menurut Siagian (dalam Sofiana, 2018) untuk mengukur variabel pelatihan karyawan dapat menggunakan beberapa indikator sebagai berikut: 
a. Pengetahuan

Pengetahuan merupakan semua milik atau isi dari pikiran. Dengan demikian, pengetahuan adalah hasil proses dari usaha manusia. Sehingga dengan adanya pengetahuan yang cukup akan membantu pekerjaan yang dilakukan cepat selesai dan dengan hasil yang baik.

b. Kemampuan berpikir

Berpikir adalah satu keaktifan pribadi manusia yang mengakibatkan penemuan yang terarah kepada suatu tujuan. Oleh sebab itu, dengan adanya kemampuan yang sesuai dengan pekerjaan yang dilakukan maka hasil dari pekerjaan akan maksimal dan baik.

c. Sikap

Sikap dapat diartikan sebagai pernyataan evaluatif, baik yang menyenangkan maupun tidak menyenangkan terhadap objek, individu, atau sebuah peristiwa. Sikap yang baik dalam menghadapi suatu masalah akan sangat membantu kelancaran pekerjaan yang dilakukan oleh karyawan.

d. Kecakapan

Kecakapan adalah suatu keterampilan yang memungkinkan seseorang untuk memperoleh pekerjaan atau untuk dapat tetap bekerja. Kecakapan yang dimiliki seorang karyawan dalam melaksankan tugasnya akan berpengaruh pada hasil yang didapatnya nanti.

C. Jam Kerja

Jam kerja adalah waktu yang ditetapkan untuk melakukan suatu pekerjaan. Sedangkan menurut Undang-undang Republik Indonesia No. 13 Tahun 2003 tentang ketenagakerjaan, jam kerja adalah waktu untuk melakukan pekerjaan, yang dapat dilakukan pada siang hari dan atau malam hari. Di Indonesia sendiri, jam kerja telah diatur oleh UU No. 13 Tahun 2003 tentang ketenagakerjaan, yaitu:

a. Setiap pengusaha wajib melaksanakan ketentuan jam kerja

b. Jam kerja sebagaimana dimaksud dalam ayat (1) meliputi:

1) 7 jam dalam 1 hari dan 40 jam dalam 1 minggu untuk 6 hari kerja dalam 1 minggu, atau

2) 8 jam dalam 1 hari dan 40 jam dalam 1 minggu untuk 5 hari kerja dalam 1 minggu.

3) Ketentuan waktu kerja sebagaimana dimaksud dalam ayat (2) tidak berlaku bagi sektor usaha atau pekerjaan tertentu

4) Ketentuan mengenai waktu kerja pada sektor usaha atau pekerjaan tertentu sebagaimana dimaksud dalam ayat (3) diatur dengan keputusan Menteri.

c. Penerapan jam kerja lembur apabila melebihi 7 jam sehari untuk 6 hari kerja dan 40 jam dalam seminggu atau 8 jam sehari untuk 8 hari kerja dan 40 jam dalam seminggu atau waktu 
Fadhila \& Ulfi.

kerja pada hari istirahat mingguan dan atau pada hari libur resmi yang ditetapkan Pemerintah.

d. Waktu istirahat dapat diartikan sebagai waktu untuk memulihkan tenaga pekerja setelah melakukan pekerjaan dalam waktu tertentu. Perusahaan juga wajib memberikan waktu istirahat bagi karyawan.

\section{METODOLOGI}

Dalam penelitian ini penulis menggunakan kuesioner atau angket kepada responden yang bekerja di PNM Mekaar Syariah di Kota Depok. Sedangkan untuk teknik analisis dalam penelitian ini penulis menggunakan pendekatan kuantitatif dengan analisis regresi linier berganda (Multiple Regression Analysis). Menurut (Yuliara, 2016) regresi linier berganda merupakan model persamaan yang menjelaskan hubungan satu variabel tak bebas/response $(\mathrm{Y})$ dengan dua atau lebih variabel bebas/predictor $(\mathrm{X} 1, \mathrm{X} 2, \ldots \mathrm{Xn})$. Penelitian ini menggunakan alat bantu kuesioner atau angket, dimana jawaban yang diberikan oleh responden diukur dengan menggunakan skala likert. Dengan skala likert, maka variabel yang akan diukur dijabarkan menjadi indikator variabel. Lalu indikator tersebut dijadikan titik tolak untuk menyusun item-item instrumen yang dapat berbentuk pertanyaan maupun pernyataan (Sugiyono, 2016).

\section{HASIL DAN PEMBAHASAN}

\section{Analisis Deskriptif Responden}

Dari hasil penyebaran kuesioner kepada 67 orang responden, yaitu karyawan PNM Mekaar Syariah di Kota Depok. Pernyataan untuk semua variabel independen $(X)$ dan variabel dependen (Y) yaitu 15 pernyataan dengan variabel X1 memiliki 5 pernyataan, X2 memiliki 3 pernyataan, dan Y memiliki 7 pernyataan. Responden dalam penelitian ini memiliki karakteristik berdasarkan pendidikan terakhir dan lama bekerja.

\section{Responden Berdasarkan Pendidikan Terakhir}

Pendidikan terakhir menjadi salah satu faktor yang mempengaruhi pertimbangan dalam penelitian ini, karena dengan adanya kriteria pendidikan terakhir penulis dapat mengetahui tingkat Pendidikan yang bekerja pada PNM Mekaar Syariah di Kota Depok. Pada gambar 1 dapat diketahui bahwa pendidikan terakhir dari 67 responden yang bekerja di PNM Mekaar Syariah Kota Depok adalah responden dengan tingkat pendidikan terakhir SMA/sederajat sebanyak 96\%, D3 sebanyak $3 \%$, S1 sebanyak 1\%, dan S2 sebanyak $0 \%$ atau tidak ada responden yang memiliki tingkat pendidikan terakhir S2. Dalam penelitian ini ternyata karyawan PNM Mekaar Syariah di Kota Depok lebih didominasi oleh karyawan yang tingkat pendidikannya SMA/sederajat. 


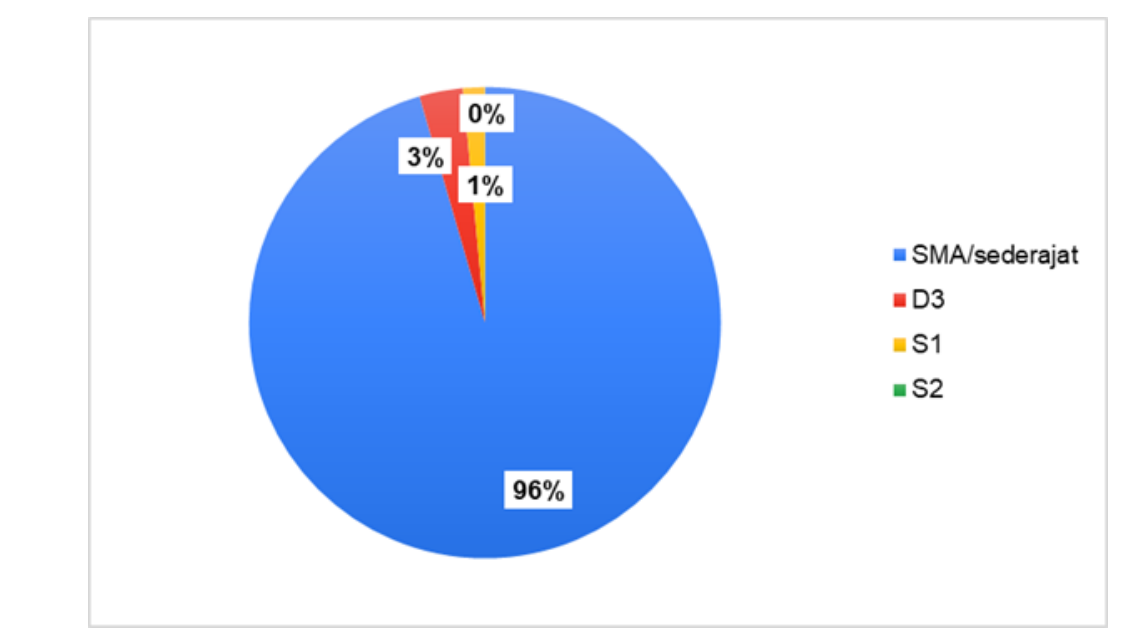

\section{Gambar 1 Diagram Responden Berdasarkan Pendidikan Terakhir}

Sumber: Data diolab dari hasil penelitian kuesioner, 2021

\section{Responden Berdasarkan Lama Bekerja}

Berdasarkan data hasil penelitian terhadap karyawan PNM Mekaar Syariah Kota Depok yang diperoleh dari kuesioner, maka didapatkan data mengenai lama bekerja sebagai berikut:

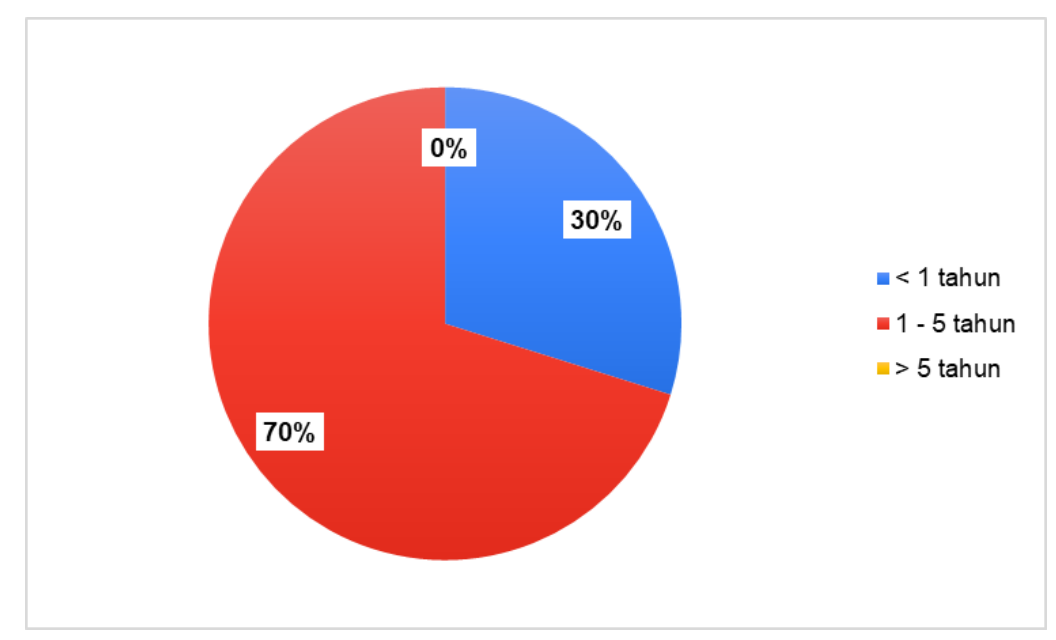

\section{Gambar 2 Diagram Responden Berdasarkan Lama Bekerja}

Sumber: Data diolah dari hasil penelitian kuesioner, 2021

Pada gambar 2 dapat diketahui bahwa dari 67 responden karyawan yang sudah bekerja selama 1-5 tahun sebanyak 70\%, (47 orang), responden dengan lama bekerja $<1$ tahun sebanyak $30 \%$ (20 orang), dan responden dengan lama bekerja $>5$ tahun sebanyak $0 \%$ atau tidak ada. Dalam penelitian ini ternyata lama bekerja karyawan lebih didominasi oleh karyawan yang telah bekerja selama 1-5 tahun dibandingkan dengan karyawan yang telah bekerja selama $<1$ tahun. 
Fadhila \& Ulfi.

\section{Analisis Deskriptif Variabel}

Setelah dilakukan penelitian dengan menyebarkan kuesioner kepada 67 responden, maka didapatkan hasil jawaban responden yaitu sebagai berikut:

\section{Tanggapan Responden Terhadap Variabel Pelatihan}

Dalam variabel pelatihan (X1) memiliki 5 (lima) butir pernyataan, dengan hasil tanggapan responden terhadap variabel pelatihan yang dijelaskan pada tabel di bawah ini:

Tabel 1. Tanggapan Responden Terhadap Pelatihan

\begin{tabular}{cccccccc}
\hline \multirow{2}{*}{ Variabel } & Pernyataan & \multicolumn{5}{c}{ Skor } & Jumlah \\
\cline { 3 - 6 } Pelatihan (X1) & STS & TS & N & S & SS & \\
& Pernyataan 1 & 0 & 0 & 2 & 49 & 16 & 67 \\
& Pernyataan 2 & 0 & 5 & 37 & 25 & 0 & 67 \\
& Pernyataan 3 & 1 & 10 & 44 & 12 & 0 & 67 \\
& Pernyataan 4 & 2 & 8 & 12 & 33 & 12 & 67 \\
& Pernyataan 5 & 0 & 6 & 15 & 36 & 10 & 67 \\
\multicolumn{2}{c}{ Jumlah } & 3 & 29 & 110 & 155 & 38 & 335 \\
Presentase & $1 \%$ & $9 \%$ & $33 \%$ & $46 \%$ & $11 \%$ & $100 \%$ \\
\hline
\end{tabular}

Sumber: Data diolah dari hasil penelitian kuesioner, 2021

Dari analisis data pada tabel 1 menunjukkan bahwa tanggapan responden terhadap variabel pelatihan terdahap kinerja karyawan PNM Mekaar Syariah di Kota Depok cukup representatif yaitu 46\% yang menyatakan setuju bahwa pelatihan menentukan kinerja karyawan PNM Mekaar Syariah di Kota Depok.

\section{Tanggapan Responden Terhadap Variabel Jam Kerja}

Dalam variabel jam kerja (X2) memiliki 3 (tiga) butir pernyataan, dengan hasil tanggapan responden terhadap variabel jam kerja yang dijelaskan pada tabel di bawah ini. Dari analisis data pada tabel 2 menunjukkan bahwa tanggapan responden terhadap variabel jam kerja terdahap kinerja karyawan PNM Mekaar Syariah di Kota Depok cukup representatif yaitu 56\% yang menyatakan setuju bahwa jam kerja menentukan kinerja karyawan PNM Mekaar Syariah di Kota Depok.

Tabel 2. Tanggapan Responden Terhadap Jam Kerja

\begin{tabular}{cccccccc}
\hline \multirow{2}{*}{ Variabel } & Pernyataan & \multicolumn{5}{c}{ Skor } & Jumlah \\
\cline { 3 - 6 } Jam Kerja (X2) & & STS & TS & N & S & SS & \\
& Pernyataan 1 & 0 & 1 & 10 & 44 & 12 & 67 \\
& Pernyataan 2 & 2 & 8 & 12 & 33 & 12 & 67 \\
& Pernyataan 3 & 0 & 6 & 15 & 36 & 10 & 67 \\
\multicolumn{2}{c}{ Jumlah } & 2 & 15 & 37 & 113 & 34 & 201 \\
\multicolumn{2}{c}{ Presentase } & $1 \%$ & $7 \%$ & $18 \%$ & $56 \%$ & $17 \%$ & $100 \%$ \\
\hline
\end{tabular}


Sumber: Data diolah dari hasil penelitian kuesioner, 2021

\section{Tanggapan Responden Terhadap Variabel Kinerja}

Dalam variabel kinerja $(\mathrm{Y})$ memiliki 7 (tujuh) butir pernyataan, dengan hasil tanggapan responden terhadap variabel kinerja yang dapat dijelaskan pada tabel di bawah ini:

Tabel 3 Tanggapan Responden Terhadap Kinerja

\begin{tabular}{cccccccc}
\hline \multirow{2}{*}{ Variabel } & Pernyataan & \multicolumn{5}{c}{ Skor } & Jumlah \\
\cline { 3 - 6 } Kinerja (Y) & STS & TS & N & S & SS & \\
& Pernyataan 1 & 2 & 0 & 7 & 32 & 26 & 67 \\
& Pernyataan 2 & 0 & 0 & 19 & 36 & 12 & 67 \\
& Pernyataan 3 & 0 & 4 & 17 & 32 & 14 & 67 \\
& Pernyataan 4 & 1 & 7 & 19 & 28 & 12 & 67 \\
& Pernyataan 5 & 0 & 1 & 5 & 47 & 14 & 67 \\
& Pernyataan 6 & 3 & 8 & 9 & 31 & 16 & 67 \\
& Pernyataan 7 & 1 & 0 & 2 & 37 & 27 & 67 \\
& 7 & 20 & 78 & 243 & 121 & 469 \\
\multicolumn{2}{c}{ Jumlah } & $1 \%$ & $4 \%$ & $17 \%$ & $52 \%$ & $26 \%$ & $100 \%$ \\
\hline \multicolumn{2}{c}{ Presentase } & & &
\end{tabular}

Sumber: Data diolah dari hasil penelitian kuesioner, 2021

Dari analisis data pada tabel 3 menunjukkan bahwa 52\% responden menyatakan setuju terhadap kinerja karena sesuai dengan pelatihan dan jam kerja pada PNM Mekaar Syariah di Kota Depok.

\section{Uji Instrumen Penelitian}

Uji validitas digunakan untuk mengukur sah atau valid tidaknya suatu kuesioner (Ghozali, 2016). Uji validitas dilakukan dengan menghitung korelasi antara skor masing-masing butir pertanyaan dengan skor total. Butir pernyataan dianggap valid jika nilai r-hitung yang merupakan nilai dari corrected item total corelation $>\mathrm{t}$-tabel.

Tabel 4 Uji Validitas

\begin{tabular}{ccccc}
\hline Variabel & Item Pernyataan & r Hitung & r Tabel & Keterangan \\
\hline Kinerja (Y) & Pernyataan 1 & 0,533 & 0,240 & valid \\
& Pernyataan 2 & 0,756 & 0,240 & valid \\
& Pernyataan 3 & 0,775 & 0,240 & valid \\
& Pernyataan 4 & 0,640 & 0,240 & valid \\
& Pernyataan 5 & 0,635 & 0,240 & valid \\
& Pernyataan 6 & 0,724 & 0,240 & valid \\
\hline
\end{tabular}


Fadhila \& Ulfi.

\begin{tabular}{ccccc}
\hline Variabel & Item Pernyataan & r Hitung & r Tabel & Keterangan \\
\hline \multirow{2}{*}{ Pelatihan (X1) } & Pernyataan 7 & 0,517 & 0,240 & valid \\
& Pernyataan 1 & 0,526 & 0,240 & valid \\
& Pernyataan 2 & 0,310 & 0,240 & valid \\
& Pernyataan 3 & 0,703 & 0,240 & valid \\
& Pernyataan 4 & 0,771 & 0,240 & valid \\
Jam Kerja (X2) & Pernyataan 5 & 0,794 & 0,240 & valid \\
& Pernyataan 1 & 0,691 & 0,240 & valid \\
& Pernyataan 2 & 0,908 & 0,240 & valid \\
\hline
\end{tabular}

Sumber: Hasil Output SPSS 25.0, 2021

Dari hasil uji validitas pada tabel 4 nilai dari setiap pernyataan pelatihan, jam kerja, dan kinerja adalah valid. Dilihat dari nilai corrected item total correlation $>\mathrm{r}$ tabel sebesar 0,240 dengan $\mathrm{df}$ $=65$ yang didapat dari $(\mathrm{df}=\mathrm{N}-2=67-2=65)$ dimana $\mathrm{N}$ merupakan jumlah responden dan dengan taraf signifikansi 0,05 .

Reliabilitas adalah tingkat seberapa besarnya suatu pengukur dengan stabil dan konsisten terhadap situasi apapun (Sugiyono, 2016). Suatu kuesioner dikatakan reliabel atau handal jika jawaban seseorang terhadap pernyataan adalah konsisten atau stabil dari waktu ke waktu. Jika nilai Cronbach Alpha > 0,60 maka kuesioner atau angket dinyatakan reliabel.

Tabel 5 Uji Reliabilitas

\begin{tabular}{lccc}
\hline \multicolumn{1}{c}{ Variabel } & Cronbach's Alpha & r Tabel & Keterangan \\
& & & \\
\hline Pelatihan (X1) & 0,648 & 0,60 & Reliabel \\
Jam Kerja (X2) & 0,764 & 0,60 & Reliabel \\
Kinerja (Y) & 0,766 & 0,60 & Reliabel \\
\hline
\end{tabular}

Sumber: Hasil Output SPSS 25.0, 2021

Berdasarkan tabel 5 dapat diketahui bahwa seluruh item variabel yang meliputi pelatihan (X1), jam kerja (X2), dan kinerja (Y) memiliki nilai cronbach's alpha $>0,6$. Oleh sebab itu, dapat disimpulkan bahwa seluruh item variabel dalam penelitian ini reliabel.

Uji normalitas digunakan untuk menguji apakah dalam model regresi antara variabel dependen dan variabel independen memiliki distribusi normal atau tidak (Sugiyono, 2016). Hasil uji SPSS versi 25.0 berdasarkan uji Kolmogorov Smirnov menujukkan bahwa nilai Monte Carlo 
Sig (2-tailed) diperoleh 0,890 berarti lebih besar dari 0,05 dan dapat dikatakan bahwa data berdistribusi normal.

Tabel 6. Uji Normalitas Kolmogorov-Smirnov

\begin{tabular}{llr}
\hline & One-Sample Kolmogorov-Smirnov Test & \multicolumn{2}{c}{$\begin{array}{c}\text { Unstandardized } \\
\text { Residual }\end{array}$} \\
N & & 67 \\
Normal Parameters & Mean & .0000000 \\
& Std. Deviation & 3.50812832 \\
Most Extreme Differences & Absolute & .069 \\
& Positive & .069 \\
& Negative & -.056 \\
Test Statistic & & .069 \\
Asymp. Sig. (2-tailed) & & $.200^{c, d}$ \\
Monte Carlo Sig. (2-tailed) & Sig. & $.890^{\mathrm{e}}$ \\
& $99 \%$ Confidence & .881 \\
& Interval & Lower Bound \\
\hline & Sumber: Hasil Output SPSS 25.0, 2021 & .898 \\
\hline & & Upper Bound
\end{tabular}

Uji multikolinearitas digunakan untuk menguji apakah dalam suatu model regresi terdapat korelasi antara variabel independen (Sugiyono, 2016). Pengujian multikolinearitas dilakukan dengan nilai Tolerance dan Variance Inflation Factor (VIF). Multikolinearitas pada suatu model dapat dilihat jika nilai VIF > 10 dan nilai tolerance tidak kurang dari 0,1 maka model tersebut dapat dikatakan terbebas dari multikolinearitas.

Tabel 7. Uji Multikolinearitas

\begin{tabular}{llcr}
\hline Model & & Coefficients $^{\mathbf{a}}$ & \multicolumn{2}{c}{$\begin{array}{c}\text { Collinearity Statistics } \\
\text { Tolerance }\end{array}$} & \multicolumn{2}{c}{ VIF } \\
1 & & & 5.648 \\
& (Constant) & .177 & 5.648 \\
\hline
\end{tabular}

Sumber: Hasil Output SPSS 25.0, 2021

Berdasarkan tabel 7 bahwa nilai tolerance $>0,1$ dan nilai VIF $<10$. Hasil tersebut dapat disimpulkan bahwa model regresi dalam penelitian ini tidak terjadi multikolinearitas antara variabel dependen dan variabel independen.

Uji heteroskedastisitas digunakan untuk menguji apakah model regresi terjadi ketidaksamaan variance dari suatu pengamatan ke pengamatan yang lain. Model regresi yang baik adalah homokedastisitas atau tidak terjadi heteroskedastisitas (Ghozali, 2016). Cara untuk 
Fadhila \& Ulfi.

memprediksi ada atau tidaknya heteroskedastisitas dapat dilihat dari pola gambar scatterplot model dan melakukan uji Glesjer (Sugiyono, 2016).

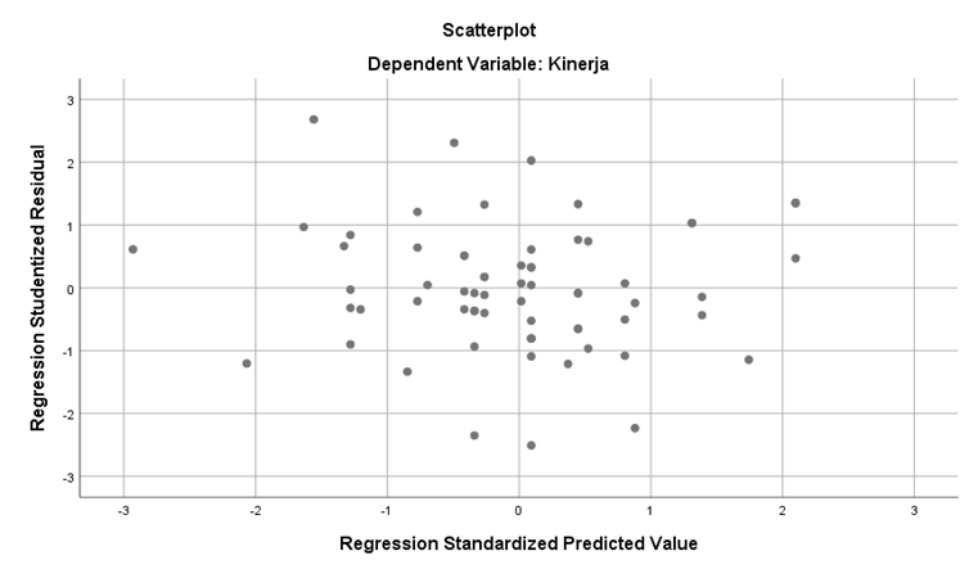

Gambar 4 Grafik Scatterplot

Sumber: Hasil Output SPSS 25.0, 2021

Berdasarkan gambar 4 terlihat titik-titik yang menyebar secara acak baik diatas maupun di bawah angka 0 pada sumbu $\mathrm{Y}$, maka dapat disimpulkan bahwa tidak terjadi heteroskedastisitas.

Tabel 8. Uji Glejser

\begin{tabular}{|c|c|c|c|c|c|c|}
\hline \multicolumn{7}{|c|}{ Coefficients $^{\mathrm{a}}$} \\
\hline \multirow{2}{*}{\multicolumn{2}{|c|}{ Model }} & \multicolumn{2}{|c|}{$\begin{array}{l}\text { Unstandardized } \\
\text { Coefficients }\end{array}$} & \multirow{2}{*}{$\begin{array}{c}\text { Standardized } \\
\text { Coefficients } \\
\text { Beta }\end{array}$} & \multirow[t]{2}{*}{$\mathrm{t}$} & \multirow[t]{2}{*}{ Sig. } \\
\hline & & $\mathrm{B}$ & Std. Error & & & \\
\hline \multirow[t]{3}{*}{1} & (Constant) & 17.634 & 4.177 & & 4.222 & .000 \\
\hline & Pelatihan & .452 & .433 & .291 & 1.044 & .301 \\
\hline & JamKerja & .097 & .506 & .054 & .193 & .848 \\
\hline
\end{tabular}

Berdasarkan tabel 8 hasil uji glejser didapatkan nilai signifikansi variabel pelatihan sebesar 0,301 > 0,05 dan nilai signifikansi variabel jam kerja sebesar 0,848 $>0,05$. Oleh sebab itu, dapat disimpulkan bahwa pada variabel pelatihan maupun jam kerja tidak terjadi gejala heteroskedastisitas dalam model regresi.

Setelah dilakukan uji normalitas, multikolinerasitas, dan heteroskedastisitas, maka langkah selanjutnya dapat dilakukan penghitungan regresi linier berganda untuk menguji hipotesis yang telah di rumuskan. Nilai konstanta sebesar 17,634 menyatakan bahwa variabel pelatihan dan jam kerja bernilai positif. Hal ini dikarenakan variabel dependen pada penelitian ini adalah kinerja karyawan PNM Mekaar Syariah di Kota Depok. Nilai koefisien regresi (b1) variabel pelatihan sebesar 0,452 menyatakan bahwa setiap ada kenaikan satu-satuan variabel pelatihan, maka kinerja akan naik sebesar 0,452 dengan asumsi variabel X lainnya tetap atau nol. Sehingga terjadi hubungan 
yang searah antara variabel pelatihan dengan kinerja karyawan PNM Mekaar Syariah di Kota Depok. Nilai koefisien regresi (b2) variabel jam kerja sebesar 0,097 menyatakan bahwa setiap ada kenaikan satu-satuan variabel jam kerja, maka kinerja akan naik sebesar 0,097 dengan asumsi variabel X lainnya tetap atau nol. Sehingga terjadi hubungan yang searah antara variabel pelatihan dengan kinerja karyawan PNM Mekaar Syariah di Kota Depok. Berdasarkan table di atas maka diperoleh nilai $\mathrm{T}$ hitung dari setiap variabel independen dalam penelitian ini. Nilai $\mathrm{T}$ hitung dari setiap variabel independen akan dibandingkan dengan nilai $\mathrm{T}$ tabel dengan menggunakan tingkat kepercayaan $95 \%$ atau $\alpha=0,05$ maka diperoleh nilai $\mathrm{T}$ tabel 1,669.

Tabel 9. Analisis Regresi Linier Berganda

\begin{tabular}{|c|c|c|c|c|c|c|}
\hline \multicolumn{7}{|c|}{ Coefficients $^{\mathrm{a}}$} \\
\hline \multirow{2}{*}{\multicolumn{2}{|c|}{ Model }} & \multicolumn{2}{|c|}{$\begin{array}{l}\text { Unstandardized } \\
\text { Coefficients }\end{array}$} & \multirow{2}{*}{$\begin{array}{c}\text { Standardized } \\
\text { Coefficients } \\
\text { Beta }\end{array}$} & \multirow[t]{2}{*}{$\mathrm{t}$} & \multirow[t]{2}{*}{ Sig. } \\
\hline & & B & Std. Error & & & \\
\hline \multirow[t]{3}{*}{1} & (Constant) & 17.634 & 4.177 & & 4.222 & .000 \\
\hline & Pelatihan & .452 & .433 & .291 & 1.044 & .301 \\
\hline & JamKerja & .097 & .506 & .054 & .193 & .848 \\
\hline
\end{tabular}

Sumber: Hasil Output SPSS 25.0, 2021

Hasil penelitian menunjukkan bahwa variabel pelatihan (X1) memiliki nilai 1,044 < 1,669 dengan signifikan 0,301 >0,05. Hal ini berarti bahwa variabel pelatihan secara parsial berpengaruh negatif dan tidak signifikan terhadap kinerja karyawan PNM Mekaar Syariah di Kota Depok. Hasil penelitian juga menunjukkan bahwa variabel jam kerja (X2) memiliki nilai 0,193 < 1,669 dengan signifikan 0,848 >0,05, hal ini berarti bahwa variabel jam kerja secara parsial berpengaruh negatif dan tidak signifikan terhadap kinerja karyawan PNM Mekaar Syariah di Kota Depok.

Dalam penelitian ini menunjukkan apakah semua variabel independen yaitu pelatihan (X1) dan jam kerja (X2) mempunyai pengaruh secara simultan terhadap variabel dependen yaitu keputusan pembelian (Y).

Tabel 10. Uji F

\begin{tabular}{|c|c|c|c|c|c|c|}
\hline \multicolumn{7}{|c|}{ ANOVA $^{a}$} \\
\hline \multicolumn{2}{|c|}{ Model } & Sum of Squares & df & Mean Square & $\mathrm{F}$ & Sig. \\
\hline 1 & Regression & 106.905 & 2 & 53.452 & 4.212 & $.019^{\mathrm{b}}$ \\
\hline & Residual & 812.260 & 64 & 12.692 & & \\
\hline & $\begin{array}{l}\text { Total } \\
\text { pendent Vari } \\
\text { dictors: (Cor }\end{array}$ & $\begin{array}{l}919.164 \\
\text { inerja } \\
\text { JamKerja, Pelatiha }\end{array}$ & 66 & & & \\
\hline
\end{tabular}


Fadhila \& Ulfi.

Berdasarkan tabel 10 maka diperolah F hitung sebesar 4,212 dengan menggunakan tingkat kepercayaan 95\% atau $\alpha=0,05$ maka dari tabel distribusi $F$ diperoleh nilai 3,14. Hasil yang diperoleh adalah $\mathrm{f}$ hitung $(4,212)>\mathrm{f}$ tabel $(3,14)$ dengan tingkat signifikansi $0,019<0,05$. Maka keputusannya adalah H0 ditolak dan H1 diterima. Dapat disimpulkan bahwa H0 ditolak dan H1 diterima yang artinya variabel pelatihan (X1) dan jam kerja (X2) berpengaruh secara simultan terhadap kinerja karyawan PNM Mekaar Syariah di Kota Depok.

Uji koefisien determinasi $\left(\mathrm{R}^{\wedge} 2\right)$ digunakan untuk mengukur seberapa jauh kemampuan model dalam rangka menerangkan variasi variabel dependen. Berdasarkan tabel di bawah terlihat bahwa koefisien determinasi yang dihasilkan sebesar 0,089 atau 8,9\% artinya bahwa pelatihan dan jam kerja yang merupakan variabel independen dapat menerangkan variabel dependen sebesar 8,9\% dan besarnya variabel lain yang memengaruhi variabel kinerja $(\mathrm{Y})$ adalah 91,1\%. Angka 91,1\% diperoleh dari $(100 \%-8,9 \%)=91,1 \%$.

Tabel 11. Uji Koefisien Determinasi

\begin{tabular}{|c|c|c|c|c|}
\hline \multicolumn{5}{|c|}{ Model Summaryb } \\
\hline Model & $\mathrm{R}$ & R Square & Adjusted R Square & $\begin{array}{l}\text { Std. Error of the } \\
\text { Estimate }\end{array}$ \\
\hline $\begin{array}{l}1 \\
\text { a. Predi } \\
\text { b. Depe }\end{array}$ & $\begin{array}{r}.341^{\mathrm{a}} \\
\operatorname{tant}), \mathrm{Ja} \\
\text { ale: Kin }\end{array}$ & $\begin{array}{r}.116 \\
\text { erja, Pelatiha }\end{array}$ & .089 & 3.56252 \\
\hline
\end{tabular}

Sumber: Hasil Output SPSS 25.0, 2021

Penelitian ini bertujuan untuk mengetahui pengaruh variabel pelatihan dan jam kerja secara parsial dan simultan terhadap kinerja karyawan PNM Mekaar Syariah di Kota Depok. Hasil penelitian menunjukkan bahwa variabel pelatihan memiliki nilai t hitung sebesar 1,044 > 1,669 dan nilai siginifikansi $0,301<0,05$. Dapat disimpulkan bahwa pelatihan tidak mempengaruhi kinerja karyawan. Meskipun dalam teori dikatakan bahwa pelatihan dapat berpengaruh terhadap kinerja karyawan, namun dalam studi kasus PNM Mekaar Syariah Kota Depok ini menunjukkan fakta yang berbanding terbalik. Hal ini disebabkan oleh pelatihan yang hanya diberikan sebanyak satu kali pada awal karyawan bekerja, tepatnya sebelum karyawan memasuki masa percobaan sehingga pelatihan yang diberikan oleh perusahaan tidak efektif dan tidak berpengaruh signifikan terhadap kinerja. Namun jika pelatihan tersebut dilakukan secara berkala seperti dua kali dalam satu tahun, mungkin saja pelatihan yang diberikan ini akan berpengaruh terhadap kinerja karyawan.

Hasil penelitian menunjukkan bahwa variabel pelatihan memiliki nilai $\mathrm{t}$ hitung sebesar $0,193>1,669$ dan nilai siginifikansi $0,848<0,05$. Dapat disimpulkan bahwa pelatihan tidak mempengaruhi kinerja karyawan. Meskipun jam kerja di lapangan tidak sesuai dengan ketentuan 
yang berlaku, namun dengan adanya penyebab lain seperti banyaknya beban pekerjaan yang harus diselesaikan. Selain itu sistem kerja yang mewajibkan para karyawan untuk menyelesaikan pekerjaan pada hari yang sama sehingga jam kerja tidak berpengaruh terhadap kinerja karyawan PNM Mekaar Syariah di Kota Depok.

Hasil penelitian menunjukkan bahwa f hitung 4,212 > f tabel 3,14 dengan tingkat signifikansi $0,019<0,05$. Hasil tersebut menjelaskan bahwa variabel pelatihan dan jam kerja berpengaruh secara simultan terhadap variabel dependen yaitu kinerja.

\section{SIMPULAN}

Berdasarkan hasil analisis yang dilakukan pada variabel pelatihan, jam kerja terhadap kinerja dalam penelitian ini, dapat disimpulkan bahwa, secara parsial berdasarkan uji t, variabel pelatihan tidak mempengaruhi kinerja karyawan PNM Mekaar Syariah di Kota Depok dengan t hitung sebesar 1,044> 1,669 dan nilai siginifikansi 0,301 < 0,05 maka Ho diterima. Secara parsial berdasarkan uji t, variabel jam kerja tidak mempengaruhi kinerja karyawan PNM Mekaar Syariah di Kota Depok dengan nilai t hitung sebesar 0,193 > 1,669 dan nilai siginifikansi 0,848<0,05 maka Ho diterima. Secara simultan berdasarkan uji f, variabel pelatihan dan jam kerja berpengaruh pada kinerja karyawan PNM Mekaar Syariah di Kota Depok dengan nilai f hitung sebesar 4,212 > f tabel 3,14 dengan tingkat signifikansi 0,019<0,05 maka Ho ditolak.

\section{REFERENSI}

Bawono, Anton. 2006. Multivariate Analysis dengan SPSS. Salatiga: STAIN Salatiga Press.

Bungin, Burhan. 2010. Metodologi Penelitian Kuantitatif. Jakarta. Kencana Prenada Media Group Ghozali, Imam. 2016. “Aplikasi Analisis Multivariete Dengan Program IBM SPSS 23 (Edisi 8). Cetakan ke-VIII. Semarang: Badan Penerbit Universitas Diponegoro.

Kosasih, Sobarsa. 2009. “Manajemen Operasi Internasional”. Mitra Wacana Media.

Naim, Mashuri Yusuf, Mursalim Umar Gani, and Rini Purnamasari. 2019. "Pengaruh Kepemimpinan Dan Pelatihan Terhadap Kinerja Karyawan Melalui Etos Kerja Pada PT. Bank Syariah Mandiri Kantor Area Makassar.” BALANCA : Jurnal Ekonomi Dan Bisnis Islam 1(2):259-80. doi: 10.35905/balanca.v1i2.1147.

Prabu, Mangkunegara, AA Anwar. 2015. Perencanaan dan Pengembangan Sumber Daya Manusia, Bandung: PT Refika Aditama,

Rojikin. 2015. Pengaruh Kompensasi dan Lingkungan Kerja Pada Kinerja Kayawan dengan Kepuasan Kerja Sebagai Variabel Interening (Study Pada PT. PLN Distribusi Jawa Tengah dan D.I Yogyakarta). Skripsi. Semarang: Universitas Negeri Semarang. 
Fadhila \& Ulfi.

Sofiana, Anisa Filia. 2018. “Analisis Pengaruh Pelatihan, Motivasi, Gaya Kepemimpinan Dan Etos Kerja Islam Terhadap Kinerja Karyawan Pada Bank Tabungan Negara (BTN) Syariah Kantor Cabang Semarang."

Sugiyono. 2016. Metode Penelitian Kuantitatif, Kualitatif, dan R\&D. Bandung: Penerbit Alfabeta Sukoco, Sugeng, Satria Tirtayasa, and Hazmanan Khair Pasaribu. 2020. "Kepemimpinan, Insentif Dan Pelatihan Terhadap Kinerja Karyawan Pada Kantor Bank Syariah Mandiri Cabang Pematang Siantar." Jurnal Manajemen Bisnis 17(2):224-39.

Undang-Undang Nomor 13 Tahun 2003 Tentang Ketenagakerjaan

Wirawan. 2009. Evaluasi Kinerja Sumber Daya Manusia: Teori Aplikasi dan Penelitian. Jakarta: Salemba Empat.

Wibowo. 2007. Manajemen Kinerja Edisi Ketiga. Jakarta: Raja Grafindo Persada.

Yuliara, I. Made. 2016. "Modul Regresi Linier Berganda.” Regresi Linier Berganda 18.

Permodalan Nasional Madani. 2021. PNM Mekaar \& PNM Mekaar Syariah. https://www.pnm.co.id/business/pnm-mekaar diakses pada 06 Februari 2021

Otoritas Jasa Keuangan. 2020. Statistik Perbankan Syariah - Agustus 2020. https://www.ojk.go.id/id/kanal/syariah/data-dan-statistik/statistik-perbankansyariah/Pages/Statistik-Perbankan-Syariah---Agustus-2020.aspx diakses pada tanggal 17 September 2020 